Case Report

\title{
Multiphasic Multidetector Computed Tomography Study of a Rare Tracheal Tumor: Granular Cell Tumor
}

\author{
Tommaso Guarnieri, ${ }^{1}$ Luciano Cardinale, ${ }^{1}$ Gianluca Macchia, ${ }^{2}$ \\ Giancarlo Cortese, ${ }^{2}$ and Andrea Veltri ${ }^{1}$ \\ ${ }^{1}$ Department of Radiology, San Luigi Gonzaga University Hospital, University of Torino, Regione Gonzole 10, 10043 Orbassano, Italy \\ ${ }^{2}$ Department of Radiology, Maria Vittoria Hospital, Via Cibrario 72, 10144 Torino, Italy
}

Correspondence should be addressed to Tommaso Guarnieri; tommasoguarnieri@yahoo.it

Received 28 July 2014; Accepted 18 November 2014; Published 8 December 2014

Academic Editor: Yiyan Liu

Copyright (C) 2014 Tommaso Guarnieri et al. This is an open access article distributed under the Creative Commons Attribution License, which permits unrestricted use, distribution, and reproduction in any medium, provided the original work is properly cited.

\begin{abstract}
Our aim is to present the case report of a woman affected by tracheal granular cell tumor analysed by multiphasic contrastenhanced multidetector CT. The tumor presents as polypoid lesion (diameter $13 \mathrm{~mm}$ ), with smooth and well-defined margins, elevated contrast enhancement in arterial phase, and a modest release of contrast in venous phase. This pattern is quite different from the other tracheal tumours. We have performed a comprehensive review of literature to assess all cases of granular cell tumors of the trachea; only 40 cases are reported. Of these, no one focused on the contrast enhancement aspect, so our work is the first showing a specific pattern in multidetector computed tomography (MDCT) of the tracheal granular cell tumour and may help in differential diagnosis.
\end{abstract}

\section{Case Report}

A 64-year-old female, complaining of progressive inspiratory dyspnoea, was brought to the emergency department of our hospital. In anamnesis only a history of heavy smoker (20 pack-year) was reported.

Chest X-ray showed signs of congestion with redistribution of pulmonary blood flow (not shown).

The patient was treated with $\mathrm{O} 2$ therapy, diuretics, and antihypertensive drugs obtaining only slight improvement so she was hospitalized.

We performed a preliminary precontrast CT (16-slice Multidetector CT, GE Medical Systems), which identified an intraluminal tracheal lesion of $13 \mathrm{~mm}$, characterised by low density $(36 \mathrm{HU})$, which occupied half diameter of tracheal lumen. The mass had smooth and well-defined border without signs of infiltration. Multiphase study showed elevated contrast enhancement in arterial phase and a modest release of contrast in venous phase (arterial phase: $120 \mathrm{HU}$; venous phase: $100 \mathrm{HU}$ ); this behaviour reflects the rich vascularity of this kind of tumor (Figures 1, 2, 3, and 4).
To assess the histology of the lesion, a biopsy was made during bronchoscopy (Figure 4(b)). The biopsy specimen was consistent with benign granular cell tumor.

The patient received endobronchial therapy (electrosurgery) and the clinical symptoms resolved. The follow-up $\mathrm{CT}$ did not show recurrence of disease.

\section{Discussion}

Granular cell tumor (also known as "Abrikossoff's tumor," "granular cell myoblastoma," "granular cell nerve sheath tumor," and "granular cell schwannoma") is a neoplasm of neural origin.

The neoplasm can affect all parts of the body with head and neck accounting for $45 \%$ to $65 \%$ of the cases (of that $70 \%$ are located in the tongue and $10 \%$ in the larynx).

Granular cell tumors are also found in the internal organs, particularly in the upper aerodigestive tract [1].

The usual presentation is of slow growing tumor. Granular cell tumors are typically solitary and are rarely larger than 


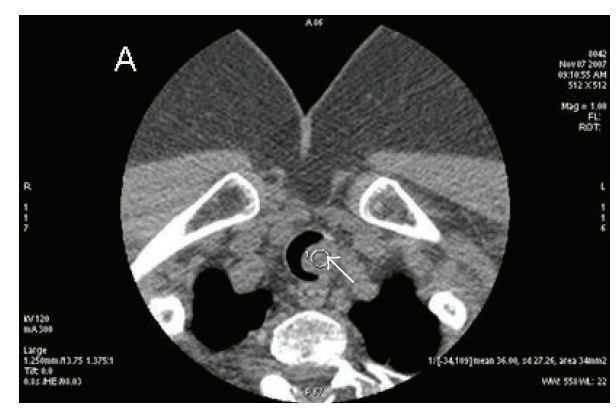

(a)

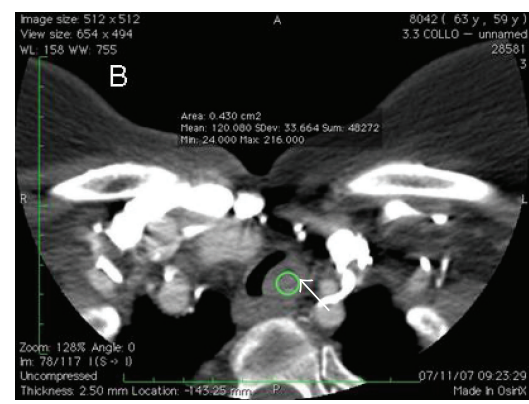

(b)

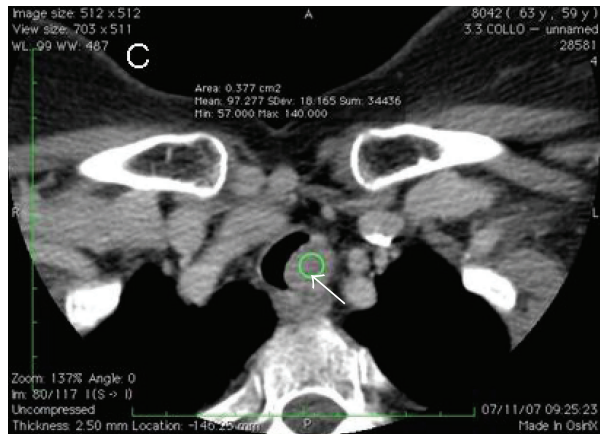

(c)

FIGURE 1: 64-year-old female with granular cell tumor of trachea. Axial multiphase contrast-enhanced CT (16-slice Multidetector CT, GE Medical Systems) demonstrating polypoid lesion (diameter $13 \mathrm{~mm}$ ) (white arrows), which presents smooth and well-defined margins and occupies the left side of the tracheal lumen. This mass does not present infiltrative signs suggestive of malignancy. The lesion shows elevated contrast enhancement in arterial phase and a modest release of contrast in venous phase; this behaviour is the tomographic expression of the rich vascularity of this kind of tumor. (a) Basal: 36 HU. (b) Arterial phase: $120 \mathrm{HU}$. (c) Venous phase: $100 \mathrm{HU}$.

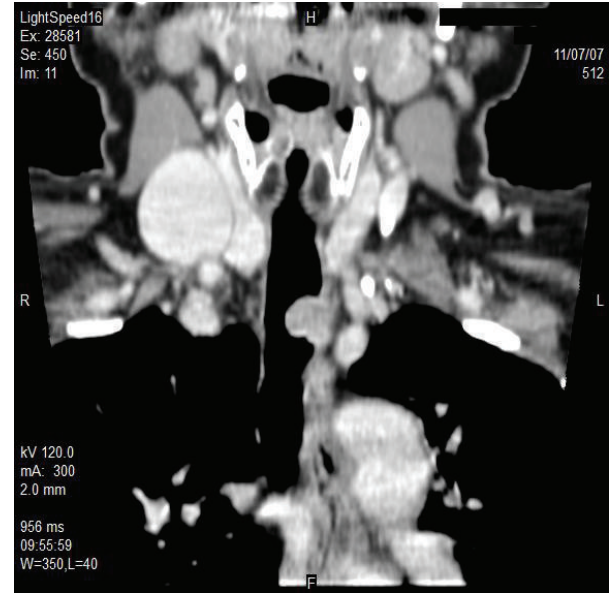

FIGURE 2: 64-year-old female with granular cell tumor of trachea. Coronal contrast-enhanced CT scan (16-slice Multidetector CT, GE Medical Systems, venous phase) obtained at the level of the aortic arch shows an eccentrical mass (white arrow) growing in the left side of trachea, occupying half of the tracheal lumen.

three centimeters. This type of tumor can be both benign and malignant, although malignancy is rare and comprises only $2 \%$ of all granular cell tumors [2]. Granular cell tumor characteristics are summarized in Table 1.

Our revision of English literature has shown only 40 cases of granular cell tumor of trachea and in all the cases

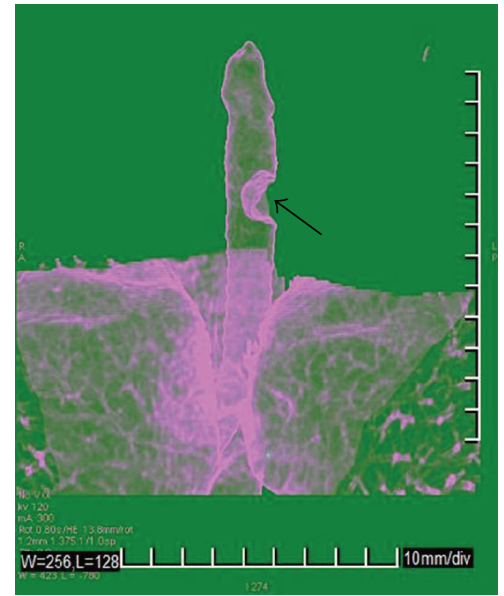

FIGURE 3: 64-year-old female with granular cell tumor of trachea. Shaded surface display (SSD) image of trachea that shows the impact of mass (black arrow) on trachea lumen (16-slice Multidetector CT, GE Medical Systems).

only clinical characteristics but not radiological images were investigated [1-8].

Our study showed a quite different pattern in comparison to the other benign tumours of trachea. The preliminary phase without contrast administration suggested the benign nature of the lesion (smooth margin, no sign of invasion) and 


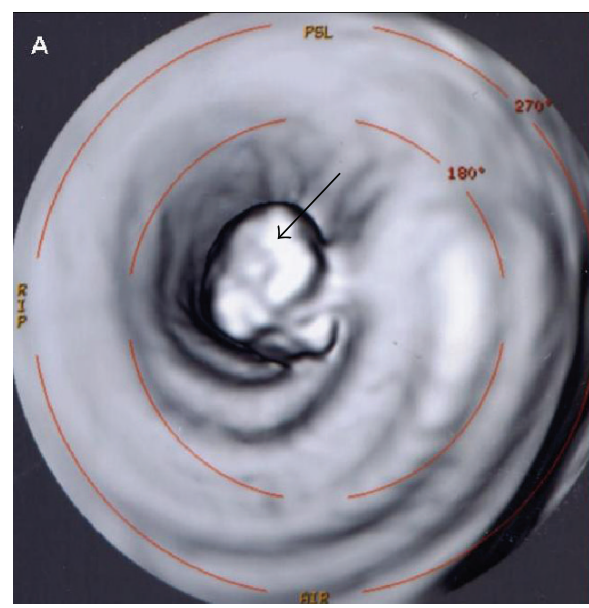

(a)

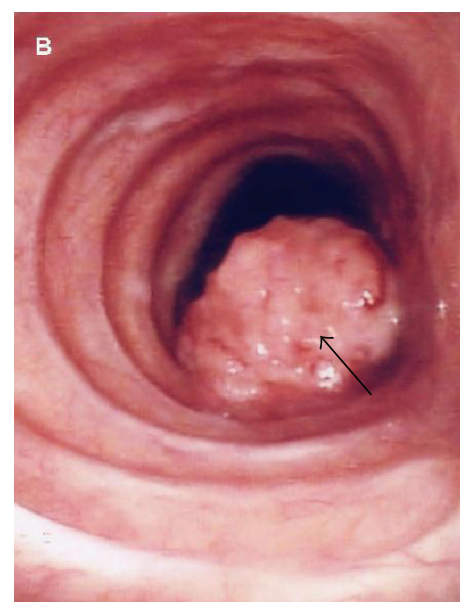

(b)

Figure 4: 64-year-old female with granular cell tumor of trachea. (a) Virtual bronchoscopy image (16-slice Multidetector CT, GE Medical Systems) and (b) real bronchoscopy image that shows intratracheal sessile lesion (black arrows), characterized by round shape and polylobulated border, originating from left wall of middle portion of trachea and protruding into trachea lumen occupying half of its diameter.

TABLE 1: Summary of granular cell tumor of trachea.

\begin{tabular}{|c|c|}
\hline Etiology & Schwann cell origin \\
\hline Incidence & Very rare, 40 cases reported in literature \\
\hline Gender & $\begin{array}{l}\text { Most granular cell tumors are found in } \\
\text { females }\end{array}$ \\
\hline Age predilection & Third and fourth decades of life \\
\hline Risk factors & $\begin{array}{l}\text { Unknown (hyperestrogenic state had been } \\
\text { hypothesized) }\end{array}$ \\
\hline Treatment & Chirurgy \\
\hline Prognosis & Good with successful resection \\
\hline Finding on imaging & $\begin{array}{l}\text { Smooth and well-defined margins, elevated } \\
\text { contrast enhancement in arterial phase, and } \\
\text { a modest release of contrast in venous phase }\end{array}$ \\
\hline
\end{tabular}

the arterial and venous phase (elevated contrast enhancement in arterial phase and a modest release of contrast in venous phase) showed differences with respect to the other benign tumour of trachea that is useful for differential diagnosis (Figure 1).

Tumors in the tracheobronchial tree are rare, accounting for less than $0.4 \%$ of all body tumors [9].

However, the vast majority of tracheobronchial tumors in adults are malignant (squamous cell carcinoma (most common), adenocarcinoma, neuroendocrine tumors (large cell neuroendocrine tumors, small cell carcinoma), adenoid cystic carcinoma (second most common), sarcoma, malignant lymphoma, and metastases) although various benign tumors may also occur in the tracheobronchial tree.

Benign tumors of trachea are about $10 \%$ of total tracheal tumors [9].

Granular cell tumor, compared with the other benign tumors of the trachea, differs in the following aspects.

(i) Hamartoma is rarely localized in trachea (in the literature hamartoma has been reported only in about ten cases); its most frequent localisation is pulmonary.
At CT this kind of tumor is characterized by low density for high adipose content and in $25 \%$ of cases shows the "popcorn" calcifications [10].

(ii) Hemangioma is more common in children, localised in trachea, and often manifests with hemoptysis [11]. It is also characterized by a rich enhancement in the arterial phase, but with filling from the periphery toward the center of the lesion.

(iii) Tracheobronchial leiomyoma occurs most commonly in the fourth decade of life, although one-third of patients are younger than 20 years old. Approximately $45 \%$ of leiomyomas are endobronchial; the rest occurs in trachea and lung.

Leiomyomas usually are small and are found incidentally during bronchoscopy performed to evaluate other lung lesions.

The lesion appears as an airway intraluminal nodule with oval, lobulated, or round edge. The internal content of tumor is homogeneous with homogeneous enhancement.

This tumor has an attenuation of $25-46 \mathrm{HU}$ on unenhanced CT and 46-85 HU on enhanced CT (less enhancement than Abrikossoff's tumor).

The rare big leiomyomas (over $40 \mathrm{~mm}$ ) can be heterogeneous with stippled calcifications and on enhanced scans these tumors have heterogeneous enhancement (this big tumor has intraluminal and extraluminal components) [12].

(iv) Lipoma of tracheobronchial tree is very rare $(0.01 \%$ of all bronchial tumors) and it is usually found endobronchially. In the majority of cases, it is located in the first three subdivisions of the tracheobronchial tree.

It has characteristic density which is very different from other tracheal tumors (from -50 to $-100 \mathrm{HU}$ ) [13].

(v) Carcinoid of the trachea is an extremely rare entity with very few cases reported in the literature, 20 cases reported in Chinese literature and 15 cases reported in English literature [14]. Carcinoids have a rich vascularity (intense arterial phase) but cause earlier symptoms than granular cell tumor because they are more often localized in 
TABLE 2: Differential diagnosis table for granular cell tumor of trachea.

\begin{tabular}{ll}
\hline Entity & CT findings \\
\hline Hamartoma & $\begin{array}{l}\text { "Popcorn" calcifications; low density for } \\
\text { adipose content }\end{array}$ \\
\hline Hemangioma & $\begin{array}{l}\text { Rich enhancement in the arterial phase, filling } \\
\text { from the periphery toward the center of the } \\
\text { lesion }\end{array}$ \\
\hline $\begin{array}{l}\text { Tracheobronchial } \\
\text { leiomyoma }\end{array}$ & $\begin{array}{l}\text { Oval, lobulated, or round contour, } \\
\text { homogeneous content with homogeneous } \\
\text { enhancement. 25-46 HU on unenhanced CT } \\
\text { and 46-85 HU on portal phase }\end{array}$ \\
\hline Lipoma & HU from -50 to -100 (density of fat) \\
\hline Carcinoid & $\begin{array}{l}\text { Rich enhancement in the arterial phase } \\
\text { (150 HU). Calcification (30\% of cases) }\end{array}$ \\
\hline
\end{tabular}

bronchial tree than in trachea, and for this reason carcinoids cause early obstruction and air trapping, mucoid stagnation, bronchiectasis, and pneumonia.

Moreover, carcinoids in $30 \%$ of cases have calcifications which are not present in the granular cell tumors.

Differential diagnoses are summarized in Table 2.

\section{Conclusion}

The CT aspect of benign tracheal tumors helps in differential diagnosis. The association of the epidemiology, the site of origin, the morphology, and in particular the characteristics of enhancement with multiphase approach can suggest the diagnosis of the nature of the tumor that must be confirmed with histological specimen.

\section{Abbreviations}

MDTC: Multidetector computed tomography

CT: Computed tomography

HU: Hounsfield unit

GE: General Electric

mm: Millimetre

MIP: Minimum intensity projection

SSD: $\quad$ Shaded surface display.

\section{Consent}

Consent was obtained from the patient.

\section{Conflict of Interests}

The authors declare that there is no conflict of interests regarding the publication of this paper.

\section{Authors' Contribution}

All authors contributed to the drawing up and correction of the paper.

\section{References}

[1] D. P. Desai, J. Maddalozzo, and L. D. Holinger, "Granular cell tumor of the trachea," Otolaryngology-Head and Neck Surgery, vol. 120, no. 4, pp. 595-598, 1999.

[2] N. Leboulanger, I. Rouillon, J. F. Papon, P. Josset, G. Roger, and E. N. Garabédian, "Childhood granular cell tumors: two case reports," International Journal of Pediatric Otorhinolaryngology, vol. 72, no. 2, pp. 279-283, 2008.

[3] M.-K. Joung, Y. J. Lee, C.-U. Chung et al., "A case of granular cell tumor of the trachea," The Korean Journal of Internal Medicine, vol. 22, no. 2, pp. 101-105, 2007.

[4] M. Yasuda, T. Hanagiri, Y. Ichiki, H. Uramoto, M. Takenoyama, and K. Yasumoto, "Surgical treatment of patients with stenosis of the central airway due to tracheal tumours," Asian Journal of Surgery, vol. 33, no. 4, pp. 212-217, 2010.

[5] R. Ipakchi, W. H. Zager, M. E. de Baca, E. Bloedon, P. A. McCue, and D. Zwillenberg, "Granular cell tumor of the trachea in pregnancy: a case report and review of literature," Laryngoscope, vol. 114, no. 1, pp. 143-147, 2004.

[6] S. Thaller, M. P. Fried, and M. L. Goodman, "Symptomatic solitary granular cell tumor of the trachea," Chest, vol. 88, no. 6, pp. 925-928, 1985.

[7] F. Stieglitz, R. Kitz, H. J. Schäfers et al., "Granular cell tumor of the trachea in a child," Annals of Thoracic Surgery, vol. 79, no. 2, pp. e15-e16, 2005.

[8] J. van der Maten, J. L. G. Blaauwgeers, T. G. Sutedja, H. B. Kwa, P. E. Postmus, and S. S. Wagenaar, "Granular cell tumors of the tracheobronchial tree," Journal of Thoracic and Cardiovascular Surgery, vol. 126, no. 3, pp. 740-743, 2003.

[9] C. M. Park, J. M. Goo, H. J. Lee, M. A. Kim, C. H. Lee, and M.-J. Kang, "Tumors in the tracheobronchial tree: CT and FDG pet features," Radiographics, vol. 29, no. 1, pp. 55-71, 2009.

[10] E. Cetinkaya, G. Gunluoglu, S. Eyhan, M. Z. Gunluoglu, and S. I. Dincer, "A hamartoma located in the trachea," Annals of Thoracic and Cardiovascular Surgery, vol. 17, no. 5, pp. 504-506, 2011.

[11] B. Z. Koplewitz, C. Springer, B. S. Slasky et al., "CT of hemangiomas of the upper airways in children," American Journal of Roentgenology, vol. 184, no. 2, pp. 663-670, 2005.

[12] Y. Kyung Kim, H. Kim, and K. Soo Lee, "Airway leiomyoma: imaging findings and histopathologic comparisons in 13 patients," American Journal of Roentgenology, vol. 189, pp. 393S399S, 2007.

[13] A. H. Nassiri, H. Dutau, D. Breen et al., "A multicenter retrospective study investigating the role of interventional bronchoscopic techniques in the management of endobronchial lipomas," Respiration, vol. 75, no. 1, pp. 79-84, 2008.

[14] A. Mukherji, P. Verma, D. Sinha, M. Sharma, and M. Pal, "Carcinoid of the trachea in a young adult male responsive to chemo-radiation," Indian Journal of Otolaryngology and Head \& Neck Surgery, vol. 63, supplement 1, pp. S13-S15, 2011. 


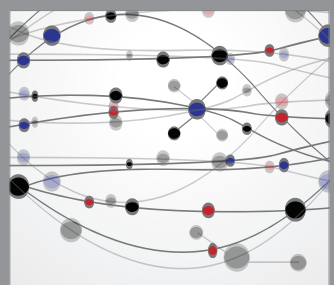

The Scientific World Journal
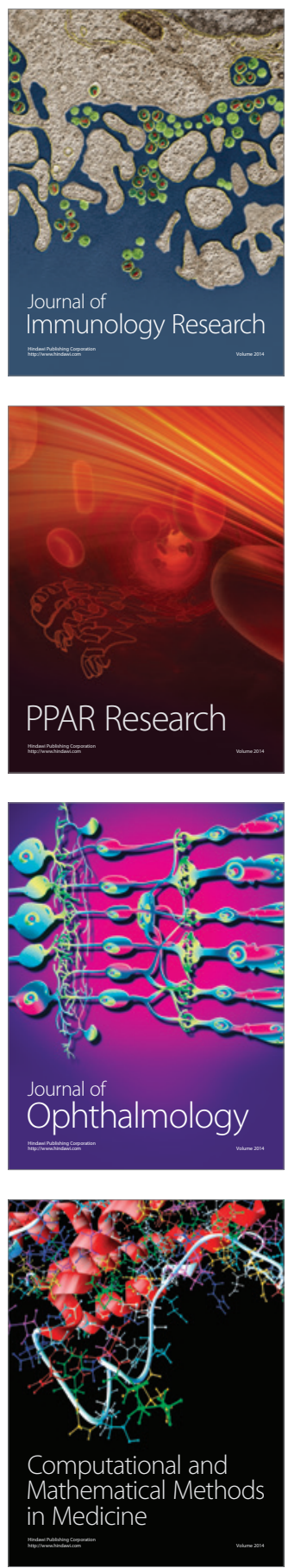

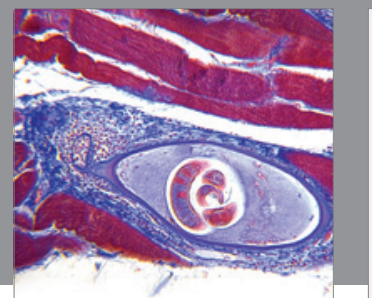

Gastroenterology

Research and Practice
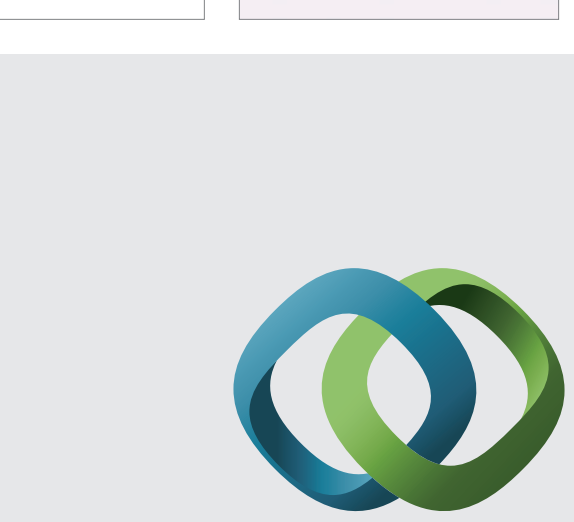

\section{Hindawi}

Submit your manuscripts at

http://www.hindawi.com
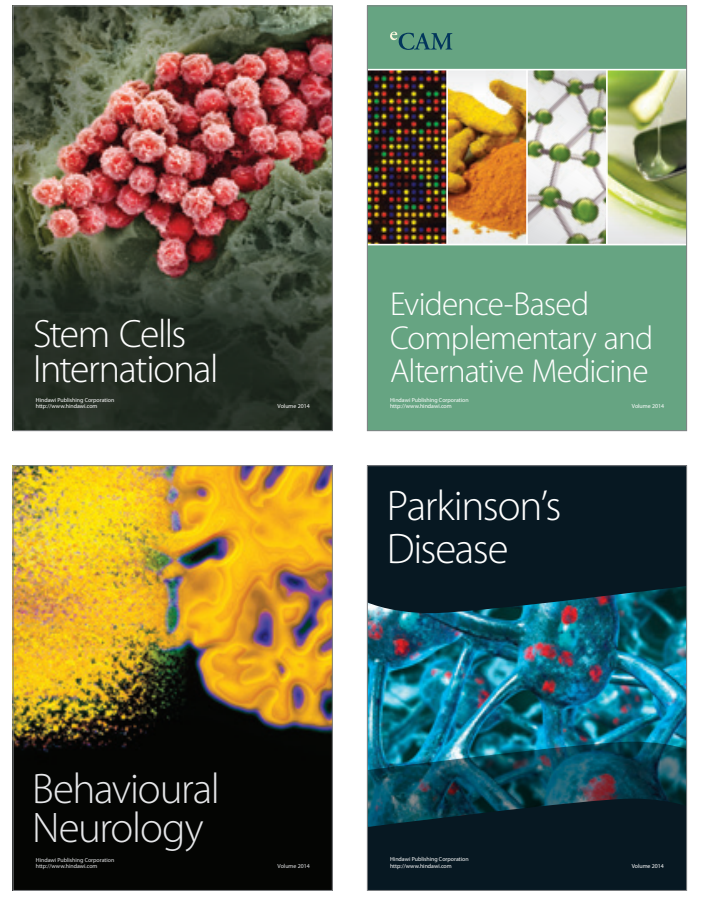
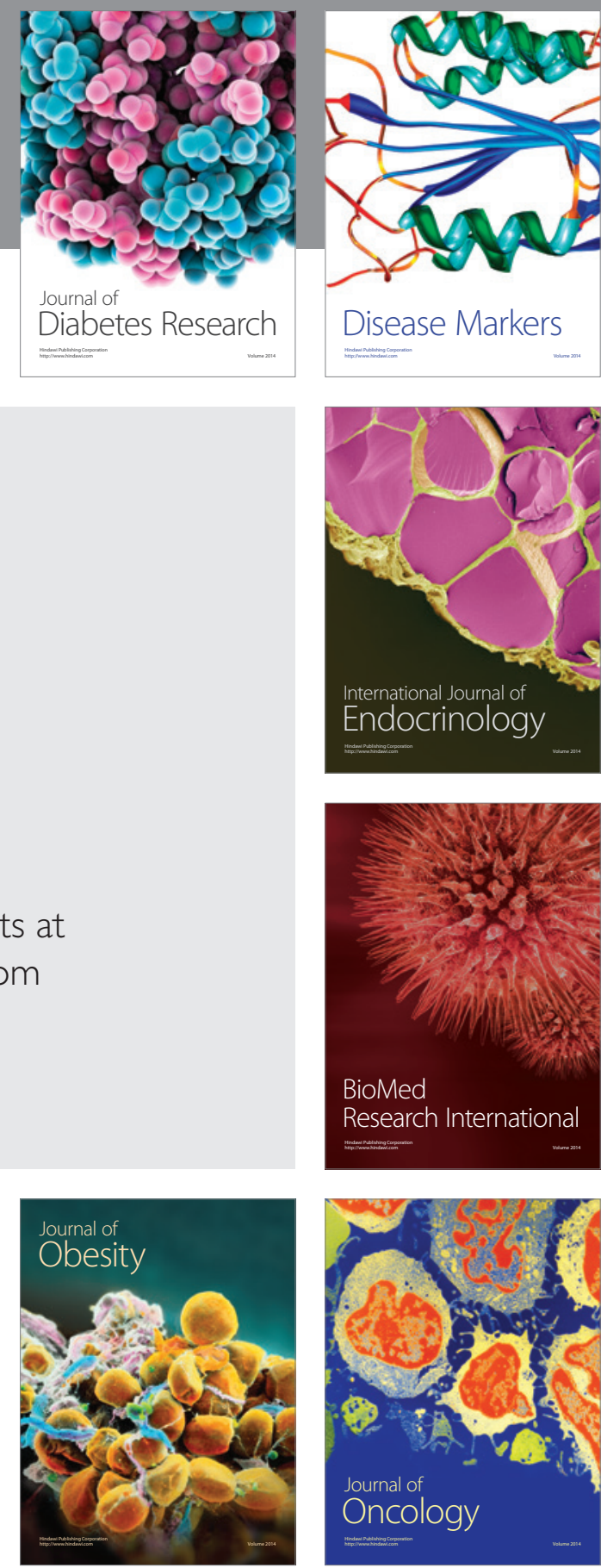

Disease Markers
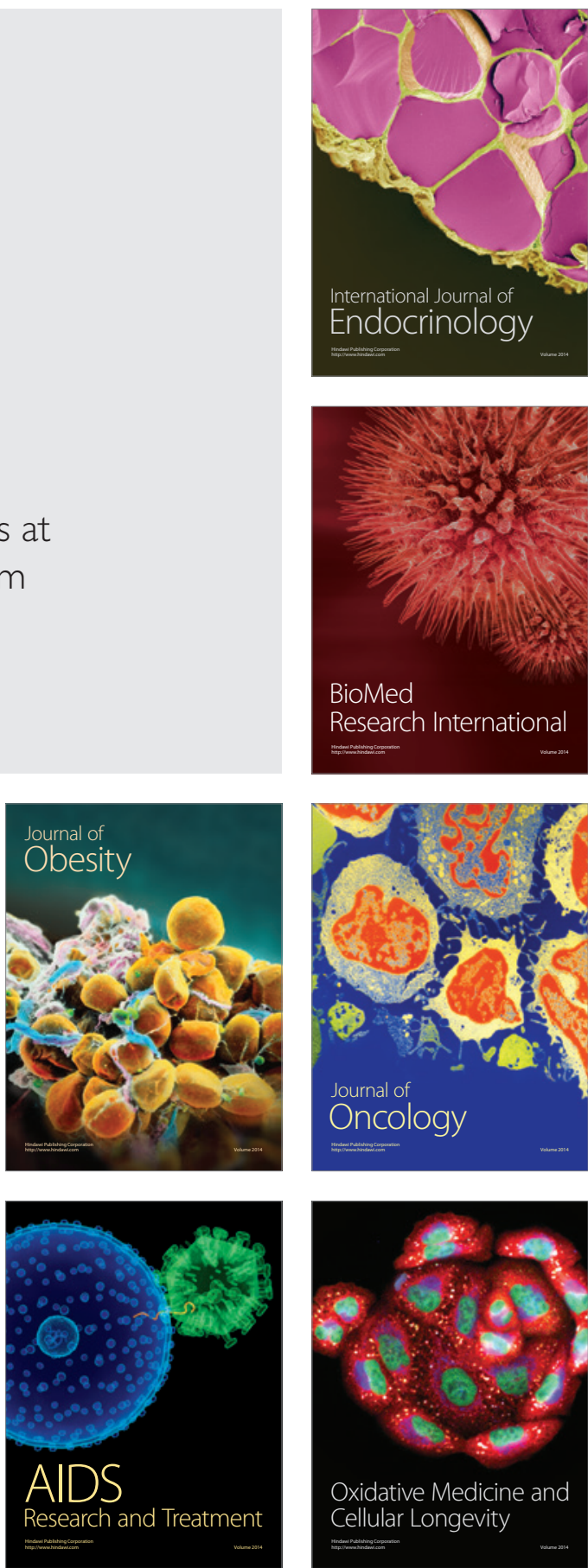